\title{
ARCHITECTURE AND CULTURAL HERITAGE MANAGEMENT TOOLS: LANDSCAPE ACTION PLANS
}

\author{
ANDER DE LA FUENTE ARANA ${ }^{1} \&$ URTZI LLANO-CASTRESANA ${ }^{2}$ \\ ${ }^{1}$ Departament of Architecture, University of the Basque Country UPV/EHU, Spain \\ ${ }^{2}$ Faculty of Engineering in Bilbao, University of the Basque Country UPV/EHU, Spain
}

\begin{abstract}
In our southern European environment, planning continues to be addressed with 19th-century zoning instruments and defined policies. The growing reaction to the impositions of this territorial policy in local areas proposes a strong bottom-up, non-urbanism of the strategic and the punctual, whose results are beginning to be insufficient due to their limited continuity and difficult coordination. The work in network and with articulated and inter-connectable projects, is revealed, however, as a tool of utility not yet sufficiently tested. To overcome the barrier between what we define as "planning" or macroterritorial policy and "ordination" at a micro level, tools such as Landscape Action Plans (LAP) are proposed. The LAP is structured as a document that, starting from the micro analysis of all facets of the landscape (not only of how it is perceived, but also of its identity generating dimension, and even of its socio-economic aspects), and listening to the demands of the citizens through social dialogue processes, raise a solution to shared problems in local or municipal areas. This solution must be defined not only formally, but applying the determinations emanated from the regional policy of Territorial Planning designed for larger areas. In the last six years, the design of LAP by our Constructed Heritage Research Group (GPAC) has yielded very interesting results in terms of coordinating municipal and regional policies, such as the Landscape Action Plans of Trapagaran (2016) and Ortuella (2018), among others. The planning of small, embraced landscapes, endowed with strong character, through Landscape Action Plans (LAP), could be an option to channel this desire for local planning into a network, which compensates or inspires a broader and more democratic territorial policy.
\end{abstract}

Keywords: landscape management tools, territorial policy, action plans, local planning network.

\section{INTRODUCTION}

The landscape concept is defined in the European Convention of 2000 as "any part of the territory as perceived by the population, whose character is the result of the action and interaction of natural and/or human factors" [1]. This definition exceeds the territory (object of planning) and landscape (object of protection) dichotomy.

Territorial planning involves the evaluation of decisions referring to a specific physical space before an action is initiated [2, p. 2]. For this reason, we usually refer to planning as a supramunicipal policy oriented towards the design of a territorial model for the future.

In territorial planning, the urban planner played the role of designer in interventions referring to urban morphology. This has been from the socially sustainable conservationism of the Garden City [3] to the extensive and dependent city of the Broadacre automobile, designed by Wright.

In the 1960s there was a reaction against planning [4]. Urbanism is relegated to proposals focused on the morphological [5, p. 312]. Geo-ecology [6, pp. 43-46] proposes the conception of the territory as a result of the dynamic human being vs. nature, against the traditional concept of geographical region.

In recent times, a specific landscape policy has been developed [7]. Often, however, these policies favour the protection of natural beauty against the urbanizing threat [8], taking up again what has been defended by North American conservationists since the mid-19th century $[9$, p. 560]. 
In this evolution, we have tried to relegate architects to a secondary and merely formal role in landscape design. In this sense, the architecture of the landscape is confused with the mere treatment of open spaces, with urban landscaping or with the design of gardens in the surroundings of cities.

However, the definition of the concept of landscape of the European Convention overcomes the separation between natural and urbanized landscape. If, up to now, urban planners were primarily concerned with formal design in the urban sphere, what task corresponds to them in landscape management, understood in a broader sense?

The integral management of the landscapes goes from identification to reflection on the impact of the proposals, going through the assessment, documentation and intervention. That is why it cannot be in the hands of a single discipline. But for the coordination of the teams in charge of each link of the process, the training in architecture is, in our opinion, adequate due to its transversal nature. This is so, as long as the scale at which this work develops involves the intervention in the management plans, not the mere definition of generic planning policies.

According to the European Charter of the Territory Planning of 1983, territorial planning constitutes "the spatial expression of the economic, social, cultural and ecological policy of the whole society" [10, p. 30]. Therefore, it involves the material concretion of the planning in the inhabited space (landscape) and of an encompassable scale. It would be a task carried out by governments agile in the management and close to the citizens, such as the municipal ones.

The planning of the territory, however, would imply the establishment of comprehensive policies for its integral management. It would be designed by public administrations, national, regional or local.

Planning aims to design processes; the ordering results in the realization of actions.

Planning and management are not neither opposed processes, nor independent. Their desirable integration constitutes, in fact, "the main means to achieve a balanced growth of the territory, through the adoption of corrective intervention policies" [11, p. 86].

Urban planners can participate in planning teams that advise on the design of comprehensive territorial policies, although they do not have specific training to develop them on their own. But they must also lead the work groups in charge of the management of the landscapes and the design of the action plans that manage the materialization, at municipal level, of said policies. And this is a field in which, for lack of sufficient training or professional intrusion, they are doing away with their responsibilities.

\section{METHODOLOGY: CHARACTER, "SPECIAL ATTENTION LANDSCAPES"} (SAL) AND LANDSCAPE ACTION PLANS

As an object of planning and its policies, we define "territory" as the area over which a public administration exercises its governance. In a broader sense, it has come to be considered synonymous with "landscape" [12].

The objectives of any territorial policy must be essentially two: to avoid the degradation of vulnerable spaces and to foresee a sustainable development of the entire territory in the medium term.

In our opinion, the most suitable normative instrument of territorial planning to avoid the degradation of a territory is the Landscape Catalogues.

These can be defined as "documents of a descriptive and prospective nature, covering the entire landscape" $[13$, p. 3$]$ of each demarcation of the territory (defined by political criteria) governed by a public administration. The Landscape Catalogues would be designed, therefore, with the double objective of analyzing and protecting the landscapes of a territory. 
The analysis of all the landscapes contained in a territory is done through the classification of the entire field in Landscape Units (LUs). The potential of LUs, is to become "a basic territorial piece on which to base landscape policy" [14, p. 430]. The identification of these LUs would be the "result of the delimitation on a map of a portion of the territory with a similar morphology and soil cover and, therefore, the result of a combination of merely structural elements and the particular relationships (social, economic, cultural), which have been established between a territory and its inhabitants, and which form part of the identity of the people who live in it" [14, p. 432].

In addition to containing the results of these corological-typological analyses, the Catalogues are also instruments that must define some landscapes that stand out for their differentiated character.

We can interpret the term "character" assuming the meaning of "signal or mark that is printed" [15], and proceed to order taxonomically all areas of the territory according to the "footprint" that society leaves on nature [16, pp. 104-106].

But we prefer to remain with the definition of the dictionary that defines "character" as "a set of qualities or circumstances of a thing, a person or a community, which distinguishes them from the others by their way of being or acting" [15] This definition is more in line with the "character" name that the Countryside Commission used to distinguish the different character areas and proceed with their differentiation [17].

From this point of view, our interest would not be so much to classify all areas of the territory, but to try to manage symbolic landscapes by their nature and strategically representative to build a country. We could call them "Special Attention Landscapes" (SAL), also "Areas of Special Scenic Interest" [15, p. 3], although they are not delimited areas, but open systems of interrelated elements.

The identification of these SALs should be a priority and should be undertaken for the entire territory governed by the public administration concerned.

These SALs must be defined in a different way to how the LUs are defined: not because of their homogeneity, but because of their systemic relations.

The scale of the SALs, normally not greater than the scale an administrative area equivalent to a municipality or commonwealth would encompass, brings them closer to the traditional area of management of the urban architect.

If the Government that designs the planning placed special emphasis on defining the relevant Strategic Action Plans (PAEs) in the territory's policy, the determinations that affect these PAEs could materialize in specific plans, which could be defined as Action Plans on the Landscape (LAP).

These "Landscape Action Plans are the management tools that, based on the Landscape Catalogues and Landscape Determinations, specify the actions to be carried out within the framework of actions for the protection, management and planning of the landscape" and "they are configured as intervention instruments for landscape management and planning" $[15$, p. 4].

The LAP is, therefore, a means for landscape management, executing the dictates of the planning policy, through concrete actions that can be carried out at the local/district level.

In this sense, the LAP must be a document based on the micro analysis of all the facets of the landscape. It must not only analyze how it is perceived, but also its identity-generating dimension, and even its socio-economic aspects. The LAP must propose a solution to everyday problems on the scale of the SAL. This solution must be defined not only formally, but applying in its scope the determinations emanated from the Catalogues and, therefore, the territorial policy designed for larger areas. 


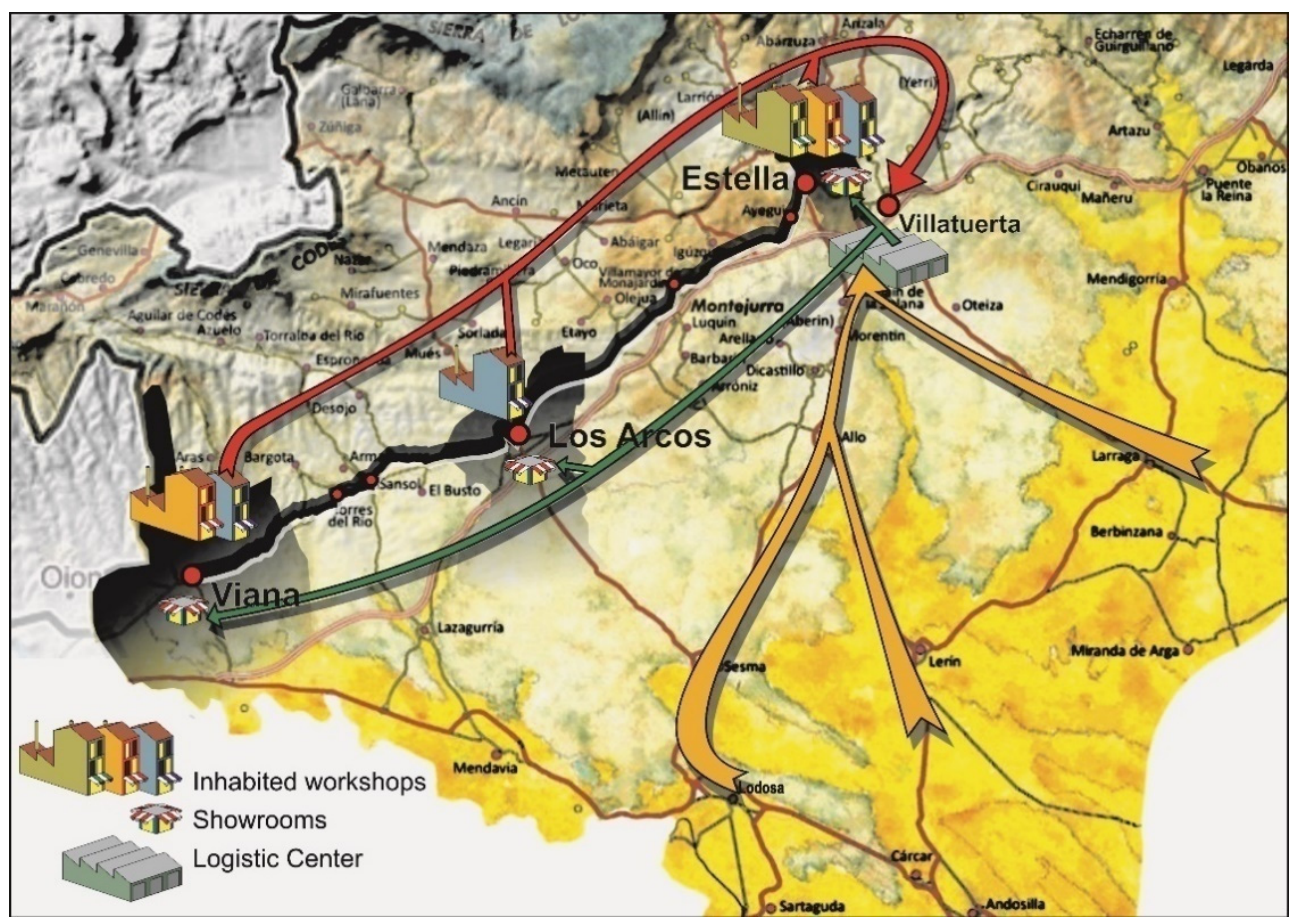

Figure 1: An example of application of the LAP tool for the management of landscapes of a Commonwealth: the landscape scope exceeds the administrative scope of the municipalities involved (Viana, Los Arcos, Estella, Villatuerta).

This would be a desirable and effective way to bridge the barrier between what we have defined as "planning" or macro territorial policy and "ordination" at a micro level.

The ultimate purpose of the LAP should be incorporated into the General Urban Planning Plans of the municipality. The joint design of actions for a specific area, with a defined character, and in accordance with a territorial policy of a much larger scope, would require binding normative support. This tool should be managed by municipalities with resolution capacity, at street level. It would also have to be designed by experts in urban planning (understood in a broad sense, not only as urban design).

Then, why is not among the attributions of the urban architect the technical coordination of the interdisciplinary teams responsible for drafting these plans? And, given that the LAPs are executive instruments for modelling landscapes, are they not they also tools to define alternative and complementary policies for territorial planning?

\section{OBTAINED RESULTS: NEW APPROACHES TO URBANISM}

We detect in our environment a growing reaction to the impositions of territorial policy in local areas. Interventionist approaches based on zoning and land use are becoming obsolete, as opposed to a strong non-urbanism of the strategic and the punctual. The bottom-up development, in its day called endogenous or local [18], gains strength compared to the traditional model from above. 


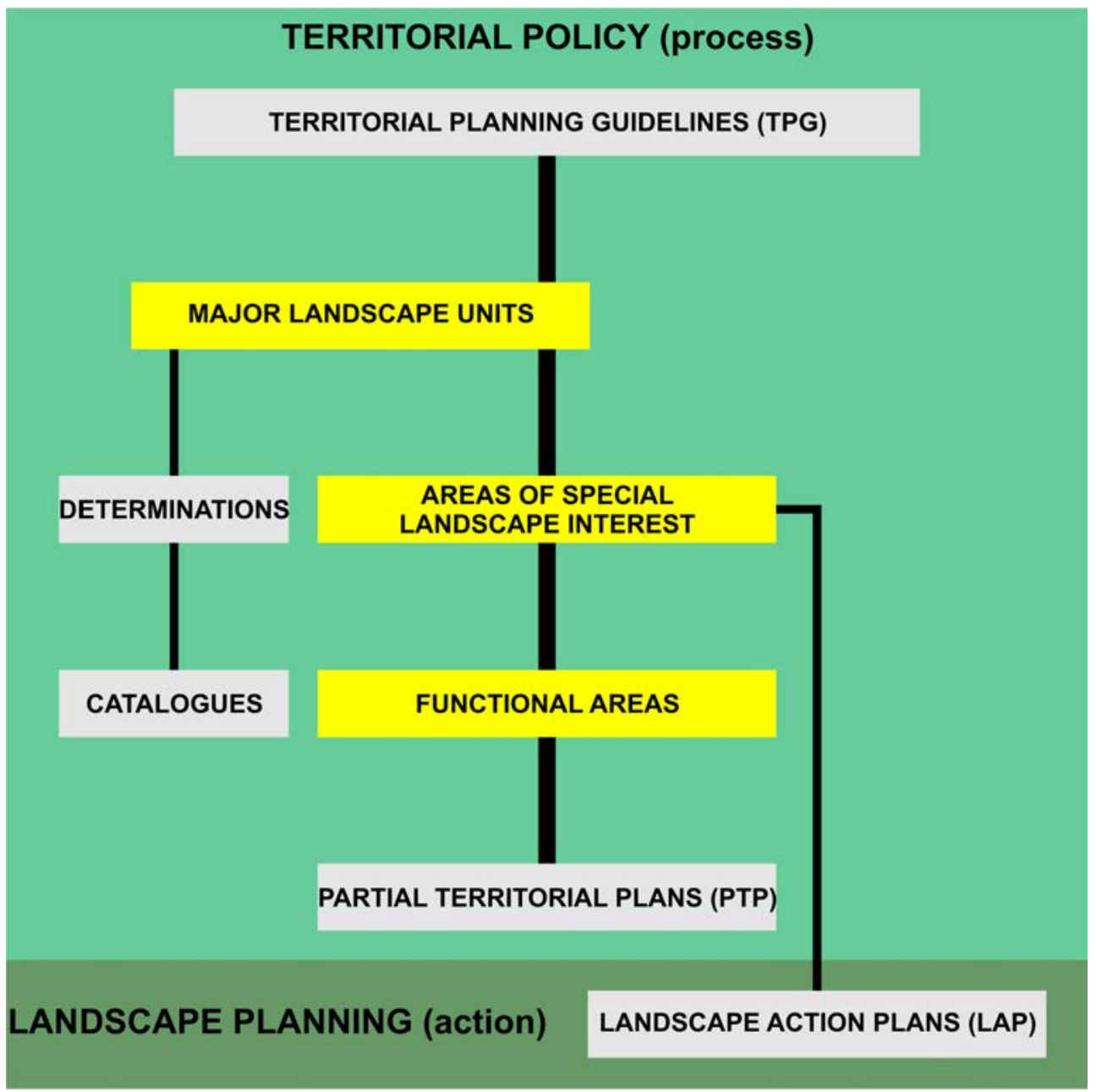

Figure 2: Scheme of territorial planning and landscape planning tools in the regulations of the Autonomous Community of the Basque Country.

New approaches to urbanism (understood as the arrangement of not only urban landscapes) are based on social capital [19]. This is channelled through strategies of cooperation and citizen participation, in order to achieve innovation and competitiveness, which arise from a reinforcement of the social cohesion of the citizens involved [11, p. 81].

Its coincidence in time with a generalized detachment of the citizens with respect to the traditional politics has set off with force the conscience of a neighbourhood empowerment. In alternative circles, usually of an urban nature, one is suspicious of the arrangement of the landscape, associating it to an imposition from the established power.

Faced with these dynamics, the planning continues to be approached with 19th-century zoning instruments, mainly concerned with the use of land and its real estate use (densities, alignments, typologies). That is why some authors argue that "when the artificial separation of functions (residential, industrial, commercial and leisure) of the modern city proves to be 
obstructive, rather than permissive, when the government abandons its poorest citizens, the latter (the poorest citizens) has no choice but to reinvent itself by transgressing the regulations" [20].

The management of this transgression requires, in order to avoid frustrations, the reduction of its actions to "micro urban practices that redirect the use of the spaces of the city in order to reverse the dynamics of certain urban environments" [21].

These actions or happenings, uncontrollably visible and fresh, have been elevated to the category of urbanism because of their ability to attract the timely collaboration of large groups of citizens. Today, there is talk of a tactical urbanism, defined as "a deliberate approach in making a city, an offer of local ideas for local planning challenges with shortterm commitments and realistic expectations, proposing low-risk interventions with the possibility of high rewards" [22].

However, if we do a necessary exercise of retrospection, the pretensions that this type of approach constitutes a solution to the disconnection of landscape management policies from the citizen's reality are not met.

In the first place, because in its nature of spontaneous actions and assembly decisions implicit is an ephemeral, improvised character. These actions hardly leave their mark on planning policies, guided by real estate interests. Having no vocation for permanence, or reversion of more general processes, these actions do not constitute any threat to the landscape dynamics dictated by large interests.

Secondly, because its alternative nature deactivates the democratic representation of all the citizens involved in the landscapes on which it intervenes. In fact, the great powers can see in these punctual interventions a tolerable and underground way of escape through which to channel social discontent, while the great lines of action marked by socio-economic agents with non-transparent interests are consumed.

Third, because in its nature of popular reaction against the dictates of the established power implicit is a character that denies the plan or the project. The direct and unprocessed realization of assembly participation is sought more. The result is materialized in hasty interventions, not always technically well resolved, that make it speak, rather than a tactical urbanism, a precarious urbanism [23].

However, we must not de-authorize the processes through which this transforming potential of our landscapes is channelled. Although they do not want to be subject to norms and to pretend to be options of raging topicality, their methodology responds to the actions already systematized in the "non-plan" trial [4]. Although they do not intend to be integrated into a systemic organization of the landscape, their aims have to do with the social structure and urban identity that arises in "death and life of the big cities" [24]. Although they do not recognize a willingness to build a global philosophy for landscape planning, their reflections take root in those that already arose fifty years ago around the public sphere of decision as an alternative to established power [25], [26].

For all these reasons, perhaps the time has come to reflect on how this citizen energy is channelled. We must question whether it has to crystallize into a spontaneous intervention or coordinated actions, which take the form of a plan arising from the expectations and basic social desires; not from the administrative policies, but agreed with them.

Designing a structured plan of local scale coherent with others that are developed for a larger scope makes possible "the simultaneous and coordinated application in a network of a local development model to the whole of a region [and] allows obtaining synergies and economies of scale that increase its effectiveness, promoting a much larger number of local initiatives than if each local territory operated separately, which, in a general way, can be called a regional model of local development in a network" [11, p. 81]. 
This concerted strategy that synchronizes specific tactical interventions does not presuppose a design that is imposed. Rather it is an informed mediation work, inspired by the Advocacy Planning [27]. It consists in the fact that the ordination technician offers to advise a social group aware of the preservation and dynamization of their landscape, putting their knowledge at their disposal. Its mission is to channel the demands, contributions, needs and proposals that arise from the public sphere. In front of it, that of the "agency planner", whether public or private, responds more to pre-established real estate or political interests.

In this role as interpreter and coordinator of the initiatives and demands arising from citizenship, without adulterating them in biased interpretations, the transversal training of architects can help. The urban architect presents an adequate technical profile, if one possesses the necessary social sensitivity and the specific tools. In fact, in our opinion, part of the future of architecture is in the change of focus on what its own object should be. It is no longer about focusing on the building or urban design. We must also dedicate ourselves to managing the landscape, as a galaxy of unfinished space constructions.

The presence of this mediator can solve the first of the previously identified problems for the usual actions of tactical urbanism: the one of its improvised, ephemeral and deletable character. But this technical elaboration always entails a certain systematization, classification and critical evaluation of the actions.

A perfectly adequate tool for this work of systematization of citizen initiatives and inclusion of local policies is, as we have indicated, that of the Landscape Action Plans (LAPs). If we are able to design the structure of these Plans in such a way that their results in different contexts at the municipal or joint-community level are convergent, we will promote the desirable network coordination of the management models. Therefore, we will enter the path of effective and lasting landscape management, managed in a bottom up way.

In fact, if we want to counteract the territorial policies of the big economic lobbies, "we have no choice but to go up in scale, recover politics, not only so that this new punk, emerging, participatory and transforming urbanism is an activity of the future, but not to commit the mistakes of the past, to make feasible what we have been preaching for half a century" [23].

\section{CONCLUSIONS}

The architecture has been too much time absorbed in the generation of machines to live or work, which were implanted indiscriminately in different contexts. From the pilotis with which Le Corbusier separated its houses from the earth to the Andante City of Cook, passing through the cold corporate headquarters erected in the International Style of Mies, architecture, with some exceptions, has ignored the landscape. The architect has become obsessed with creating object-buildings; sometimes mimicked with the surrounding nature, under the influence of Wrightian organicism; too many times at the service of speculative economic interests.

Faced with the alienating landscape built in large real estate operations, politics has reacted late and with outdated methods. Protectionist proposals based on the freezing of areas of "natural or cultural interest" have been launched. The "intermediate territories" have been ordered by means of zoning, building densities and land uses [28, p. 200].

Faced with this situation, citizens begin to react spontaneously as far as they can. Thus, they try to manage the interstices and small areas that real estate speculation has left abandoned for not very profitable.

The results of these micro-initiatives are beginning to be insufficient, due to their difficult continuity over time and the weakness of their coordination. In response, networking and articulated and interconnected projects are revealed as a useful tool not yet sufficiently tested. 
In this context, the planning of small, encompassable landscapes, endowed with strong character, through Landscape Action Plans (LAPs), could be an option to channel this desire for local networked planning. A coordination of these local dynamics would consequently lead to a more democratic territorial policy.

\section{REFERENCES}

[1] Council of Europe, 1st article, Convenio Europeo del Paisaje, Ediciones del Ministerio de Cultura, Madrid, 2008, Ministerio de Medio Ambiente: Madrid, 2007 [2000].

[2] Van Gusteren, H.R., The Quest of Control: A Critique of the Rational Control Rule Approach in Public Affairs, Wiley: New York, 1976.

[3] Howard, E., To-morrow: A Peaceful Path to Real Reform, Swan Sonnenschein: London, 1898.

[4] Banham, R., Barker, P., Hall, P. \& Price, C., Non Plan: An experiment in freedom. New Society, 338, 1969.

[5] Rossi, A., La Arquitectura de la Cudad, 10th ed., Gustavo Gili: Barcelona, 1992.

[6] Troll, C., Landscape ecology (geoecology) and biogeocoenology: A terminology study. Geoforum, 8, pp. 43-46, 1971.

[7] Ormaetxea, O. \& Saenz de Olazagoitia De la Riva, A., Nuevos requerimientos y herramientas en el estudio del paisaje de la Comunidad Autónoma del País Vasco: un ejemplo de aplicaciónp. Análisis espacial y representación geográfica: innovación y aplicación, Universidad de Zaragoza-AGE, pp. 1163-1172, 2015.

[8] Hildenbrand, A., Paisaje y política de ordenación del territorio. Análisis de la experiencia internacional comparada, 3 vols, Junta de Andalucía: Sevilla, 1993.

[9] Marsh, G.P., Man and Nature or Physical Geography as Modified by Human Action, C. Scribner, 1864.

[10] Gómez Orea, D., Ordenación Territorial, Editorial Agrícola Española, SA, Mundi Prensa: Madrid, 2001.

[11] Precedo, A. \& Míguez, A., La evolución del desarrollo local y la convergencia territorial. Perspectivas teóricas en desarrollo local, ed. M. García Docampo, La Coruña, 2007.

[12] Ingold, T., Hunters Pastoralist and Ranchers: Reindeer Economies and their Transformation, Cambridge University Press: Cambridge, 1980.

[13] BOPV, Boletín Oficial del País Vasco, 112, 16 Jun. 2014.

[14] Nogué, J., El paisaje en la ordenación del territorio. La experiencia del Observatorio del Paisaje de Cataluña. Estudios Geográficos, 71(269). pp. 415-448, 2010.

[15] RAE, Diccionario de la Lengua Española, 22nd ed., Real Academia Española, 2001.

[16] Besse, J.M., Voir la Terre. Six essais sur le paysage et la géographie. Arlés: Actes du Sud ENSP/Centre du Paysage, Biblioteca Nueva: Madrid, 2010.

[17] Countryside Commission, Countryside Character. The Character of England's natural and man-made landscape. Countryside Commission, vol. 3, Yorkshire and The Humber: London, 1998.

[18] Vázquez-Barquero, A. \& Garofoli, G., Desarrollo económico local en Europa, Economistas Libros: Madrid, 1995.

[19] Camagni, R., Incertidumbre, capital social y desarrollo local: enseñanzas para una gobernabilidad sostenible del territorio. Investigaciones Regionales, 2, pp. 31-58, 2003.

[20] Polyak, L., The rules of space: Regulation and resistance in Budapest's public spaces. Kontrolle öffentlicher Räume. Unterstützen Unterdrücken Unterhalten Unterwandern, 
eds E.T. Bertuzzo, E.B. Gantner, J. Niewöhner \& H. Oevermann, LIT Verlag: Berlin, 2012.

[21] Stickells, L., The right to the city: Rethinking. architecture's social significance, Architectural. Theory Review, 16(3), pp. 213-227, 2011.

[22] Lydon, M., Tactical urbanism2: Short term action/long term change, Street Plans Collaborative, 2012. www.cnu.org/cnunews/2012/03/tacticalurbanism20. Accessed on: 22 Mar. 2018.

[23] Marrades, R., No lo llaméis urbanismo emergente; llamadlo urbanismo precario. La ciutat construida, 2014. www.eldiario.es/cv/laciudadconstruida/llameis-urbanismoemergente-llamadlo-precario_6_334276572.html. Accessed on: 20 Mar. 2018.

[24] Jacobs, J., The Death and Life of Great American Cities (Original edition published by Random House: New York, 1961), Muerte y vida de las grandes ciudades, 2nd ed., 1973 (1st ed., 1967), Ediciones Península: Madrid, 1973.

[25] Habermas, J., Student und Politik, Neuwied/Berlin: Luchterhand, 1961.

[26] Arendt, H., The Human Condition, University of Chicago Press: Chicago, 1958.

[27] Davidoff, P., Advocacy and pluralism in planning. Journal of the American Institute of Planners, 31(4), pp. 331-338, 1965.

[28] Agudo, J., Paisaje y gestión del territorio. Revista Jurídica de la Universidad Autónoma de Madrid, 15, pp. 198-237, 2004. 